\title{
THE COMPOSITION AND BIOSYNTHESIS OF LIPIDS IN HUMAN ADIPOSE TISSUES *
}

\author{
By ALFRED GELLHORN AND PAUL A. MARKS
}

\author{
(From the Department of Medicine, Columbia University College of Physicians and Surgeons, \\ and the Medical Service, Francis Delafield Hospital, New York, N. Y.)
}

(Submitted for publication January 9, 1961; accepted February 3, 1961)

The capacity of adipose tissue in rats and mice to synthesize fatty acids and triglycerides from acetate, glucose and long chain fatty acids and to oxidize these substrates to $\mathrm{CO}_{2}$ has been well established (1-5). In this investigation, a study has been made of lipid biosynthesis and lipid composition of human adipose tissues.

Human subjects provide a unique opportunity to compare the metabolism of normal subcutaneous adipose tissue with a benign neoplasm of fat tissue, the lipoma. Comparative studies of most tumors with their normal tissue counterpart have been difficult because of cellular nonhomogeneity of both normal tissues and tumors and the inability to obtain tumor and normal control tissue from the same subject. The lipoma, on the other hand, arises most frequently in the subcutaneous adipose tissue and morphologically is indistinguishable from normal adipose tissue. This makes it possible to examine the synthetic and catabolic activities and composition of the tumor and control tissue in the same subject under identical environmental conditions.

In the present studies, it has been found, in vitro, that lipomas had a significantly higher rate of acetate incorporation into the mixed lipids than the normal subcutaneous adipose tissue of the same subject. Although the rate of synthesis of individual fatty acids was greater in the lipoma than in the normal fat, the relative distribution of radioactivity among the fatty acids was the same in the two tissues. These tissues did not differ significantly with respect to the rate of oxidation of acetate to $\mathrm{CO}_{2}$ or the rate of transfer of newly synthesized lipids into the medium.

* This work was supported in part by Grant CY-2332 of the National Cancer Institute, U. S. Public Health Service, The Alma Toorock Memorial Fund and the Evelyn R. Hill Fund. A portion of these data has been presented in the Proceedings of the International Symposium on Drugs Affecting Lipid Metabolism, Milan, 1960.
Despite the differences in the rate of incorporation of acetate into the mixed lipids, the fatty acid composition of the normal subcutaneous fat and the lipoma did not differ qualitatively or quantitatively. In addition, there was impressive constancy of the fatty acid composition of the normal fat and lipoma among the subjects studied despite wide variation in the rates of lipid synthesis by these tissues from one person to the next.

\section{MATERIALS AND METHODS}

Twenty patients with subcutaneous lipomas provided the material for this study. The tumors were removed under block local anesthesia together with a sample of adjacent normal adipose tissue. All patients had eaten 3 to 5 hours prior to the operation. On removal, the tissues were kept at about $5^{\circ} \mathrm{C}$ until they were prepared for incubation. The fibrous tissue capsules of the lipomas were dissected away and tissue slices of the tumor and the normal subcutaneous adipose tissue were prepared with a Stadie tissue slicer (6). Usually 1 hour elapsed between the operative removal of tissue and the beginning of incubation.

Incubation was carried out in $50 \mathrm{ml}$ Warburg-type flasks employing rubber serum bottle stoppers to seal the flasks. One to two $\mu \mathrm{c}$ of acetate-1- $\mathrm{C}^{14}, 0.1 \mathrm{ml} 1 \mathrm{M}$ glucose and varying amounts of nonradioactive sodium acetate were placed in the side-arm. Into the main compartment were added 150 to $300 \mathrm{mg}$ of tissue and an amount of Krebs-Ringer bicarbonate solution (7), containing 5 to 10 per cent of the patient's own serum, sufficient to make a final volume of $5 \mathrm{ml}$. In most experiments a flask was set up, identical with those just described except that boiled rather than fresh tissue was employed. The flasks were gassed with 95 per cent $\mathrm{O}_{2}, 5$ per cent $\mathrm{CO}_{2}$ for 5 minutes. After 20 minutes of temperature equilibration at $37^{\circ} \mathrm{C}$ in a Dubnoff metabolic shaker-bath, the reaction was begun by tipping into the main compartment the contents of the side-arm. The duration of incubation was usually 2 and 4 hours. In preliminary experiments it was established that, under the present experimental conditions, the rate of incorporation of acetate-1- $\mathrm{C}^{14}$ into the mixed lipids or into $\mathrm{C}^{14} \mathrm{O}_{2}$ by normal adipose tissue and lipoma slices was linear over a 6 hour period.

At the completion of incubation, the flasks were chilled in chipped ice. A 30 per cent solution of $\mathrm{KOH}$ was in- 
troduced into the center well, $1 \mathrm{ml} 0.2 \mathrm{~N} \mathrm{H}_{2} \mathrm{SO}_{4}$ was added to the medium in the main compartment and the flasks were shaken in ice for another 30 minutes. The $\mathrm{KOH}$ and $\mathrm{H}_{2} \mathrm{SO}_{4}$ additions were made by needle puncture through the rubber stopper.

In nine experiments, the radioactivity of the lipids in the tissue and in the medium was analyzed separately. In these studies, at the completion of the incubation period, the flask contents were poured through a fine-mesh, stainless steel screen. The tissue was repeatedly washed with either distilled water or dilute ammoniacal ethanol. Lipids were then extracted from the medium and tissue as described below.

$\mathrm{C}^{14} \mathrm{O}_{2}$ assay. The $0.2 \mathrm{ml}$ of 30 per cent $\mathrm{KOH}$ solution in the center well was transferred quantitatively to centrifuge tubes and saturated $\mathrm{BaCl}_{2}$, was added to precipitate the carbonate. The $\mathrm{BaCO}_{3}$ was washed repeatedly with water until the samples obtained from flasks with boiled tissue (blanks) showed negligible radioactive contamination (less than 0.06 per cent of the added counts). The $\mathrm{BaCO}_{3}$ was suspended in a mixture of diphenyloxazole, 0.3 per cent, and thixin, 2.5 per cent, in toluene and

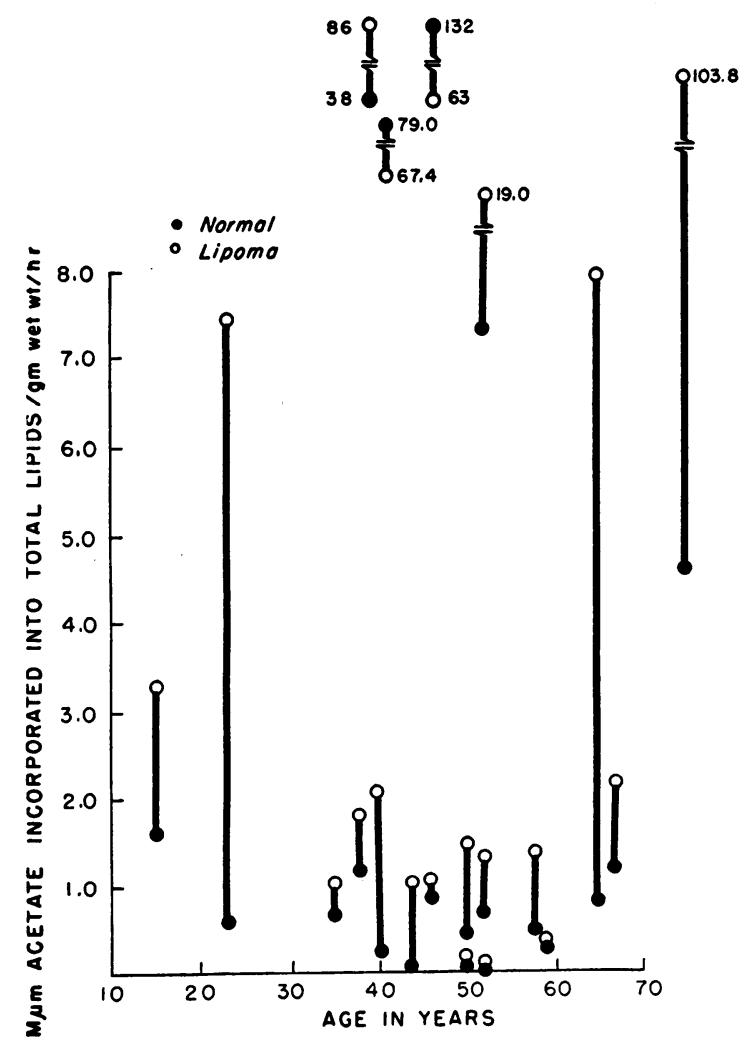

Fig. 1. The rate of incorporation of acetate into NORMAL ADIPOSE TISSUE AND LIPOMA CORRELATED WITH THE AGE OF EACH OF 20 sUBJECTS. The calculation of acetate incorporated into the total mixed lipids is based on the initial specific activities of the acetate in the incubation medium and the total radioactivity incorporated into the lipids.
TABLE I

Nitrogen and lipid content of normal adipose tissue and lipoma

\begin{tabular}{lccccc}
\hline & $\begin{array}{c}\text { No. of } \\
\text { subjects* }\end{array}$ & Nitrogen & SEM $\dagger$ & Lipid & SEM $\dagger$ \\
\hline & $\begin{array}{c}m g / g \\
\text { wet wt }\end{array}$ & & $\begin{array}{c}m g / g \\
\text { wet wt }\end{array}$ \\
Normal & 20 & 5.85 & \pm 0.48 & 630 & \pm 9 \\
Lipoma & 20 & 2.78 & \pm 0.32 & 810 & \pm 9 \\
\hline
\end{tabular}

*At least 4 aliquots of tissue were analyzed from each subject.

tSEM is the standard error of the mean.

counted in a liquid scintillation spectrometer (8). It was demonstrated in preliminary experiments that quenching of radioactivity did not occur when as much as $2.5 \mathrm{~g}$ $\mathrm{BaCO}_{3}$ was added. Radioactivity was measured in this system with an absolute efficiency of 75 per cent and a background of $30 \mathrm{cpm}$.

Extraction of lipids. The mixed lipids of the tissues or medium were extracted and prepared for analysis by a modification of the methods described by Folch, Lees and Sloane Stanley (9). The sample to be extracted was homogenized in a multimixer employing 80 to $100 \mathrm{ml}$ $\mathrm{CHCl}_{3}-\mathrm{CH}_{3} \mathrm{OH}(2: 1)$. In order to free the lipid extracts of nonlipid radioactive compounds, they were placed in viscose tubing and dialyzed against running tap water in a rotatory dialyzer for 12 to 16 hours. It was demonstrated that this method completely removed radioactive materials from boiled tissue samples which were carried through all steps of the experimental procedure. It was also found that there was no detectable loss of $\mathrm{C}^{14}$-labeled tripalmitin added to a blank sample after 24 hours of continuous dialysis.

After dialysis, the mixed lipid extract was taken to dryness under reduced pressure and made up to a known volume with petroleum ether ( $b p 30$ to $60^{\circ} \mathrm{C}$ ). An aliquot was taken for analysis of radioactivity and lipid content.

Lipid fractionation. Free fatty acid, triglyceride and triglyceride fatty acids were separated by a modification of the method of Borgström (10). An aliquot of the mixed lipid extract in petroleum ether was taken to dryness and redissolved in $\mathrm{CCl}_{4}$. To obtain the free fatty acids, the $\mathrm{CCl}_{4}$ was repeatedly washed with 0.5 per cent $\mathrm{NH}_{4} \mathrm{OH}, 0.2 \mathrm{M} \mathrm{KCl}$ in 40 per cent $\mathrm{CH}_{3} \mathrm{OH}$. Carrier, nonradioactive palmitic acid was added to the $\mathrm{CCl}_{4}$ to facilitate the free fatty acid extraction. The ammoniacal methanol solution of fatty acids was acidified with $\mathrm{H}_{2} \mathrm{SO}_{4}$ and the free fatty acids extracted with petroleum ether (bp 30 to $60^{\circ} \mathrm{C}$ ). The petroleum ether extract of the fatty acids was washed with water until the wash was neutral and then dried over anhydrous $\mathrm{Na}_{2} \mathrm{SO}_{4}$.

The $\mathrm{CCl}_{4}$ solution containing the triglycerides from which the free fatty acids had been extracted was divided into two parts, one for the determination of the radioactivity of the triglycerides and the other for hydrolysis (by refluxing in 5 per cent $\mathrm{H}_{2} \mathrm{SO}_{4}$ in $\mathrm{CH}_{3} \mathrm{OH}$ for 2 hours) to recover the triglyceride fatty acids. The 
TABLE II

The mean ratios of acetate incorporation into mixed lipids and acetate oxidation to $\mathrm{CO}_{2}$ of lipoma to normal

\begin{tabular}{|c|c|c|c|c|c|c|c|}
\hline \multirow[b]{2}{*}{ No.* } & \multicolumn{7}{|c|}{ Lipoma/normal } \\
\hline & \multicolumn{3}{|c|}{ Acetate incorporated into mixed lipid $(\mathrm{m} \mu \mathrm{moles} / \mathrm{hr})$} & & \multicolumn{3}{|c|}{ Acetate oxidized to $\mathrm{CO}_{2}(\mathrm{~m} \mu \mathrm{moles} / \mathrm{hr})$} \\
\hline 20 & $\begin{array}{l}\text { Per g wet wt } \\
4.77^{ \pm} 1.29 \dagger\end{array}$ & $\begin{array}{l}\text { Per mg N } \\
13.34 \pm 5.46\end{array}$ & $\begin{array}{l}\text { Per g lipid-free wt } \\
8.67^{\prime} \pm 3.40\end{array}$ & 14 & $\begin{array}{l}\text { Per g wet wt } \\
1.10 \pm 0.15\end{array}$ & $\begin{array}{l}\text { Per mg N } \\
2.04 \pm 0.44\end{array}$ & $\begin{array}{l}\text { Per g lipid-free wt } \\
1.80 \pm 0.40\end{array}$ \\
\hline
\end{tabular}

* No. refers to the number of separate experiments on which the mean is based.

$\dagger$ Standard error of the mean.

radioactivity of the various lipid fractions was assayed in a liquid scintillation spectrometer employing toluene containing 0.3 per cent 2,5-diphenyloxazole and 0.03 per cent $p$-bis [2-(phenyloxazolyl)] benzene as a solventphosphor system.

Fatty acid analysis. An aliquot of the mixed lipid extract was hydrolyzed and methylated by refluxing for 2 to 3 hours with 5 per cent $\mathrm{H}_{2} \mathrm{SO}_{4}$ in dry methanol at $70^{\circ} \mathrm{C}$. The methyl esters of the fatty acids thus formed were extracted with petroleum ether and the extract was taken to dryness in a nitrogen atmosphere. The fatty acid methyl esters were analyzed by gas-liquid chromatography at $185^{\circ} \mathrm{C}$ in the Barber-Coleman apparatus with a radium source ionization detector. The mobile phase was argon gas and the stationary phase was either ethylene glycol adipate or ethylene glycol succinate, 12 to 17 per cent, on 80 to 100 mesh Chromosorb W (11$13)$.

The determination of the radioactivity present in the individual fatty acids and their specific activities was achieved by splitting the effluent gas stream coming from the column. One part of the effluent gas passed through the detector cell, the other to an anthracene-filled glass cartridge outside of the apparatus which effectively trapped the fatty acid (14). The cartridges were changed manually to collect the desired fractions as indicated by the tracing which was being recorded simultaneously. The radioactivity on the anthracene was determined in the scintillation spectrometer by inserting the glass cartridge into the well of a Lucite sphere which had the same dimensions as the conventional liquid counting bottle.

\section{RESULTS}

Lipid biosynthesis and acetate oxidation in normal adipose tissue and lipoma. In 18 of 20 sub- jects, the rate of acetate incorporation into mixed. lipids of lipoma was higher than that of the adjacent normal adipose tissue (Figure 1). In some persons the normal adipose tissue synthesized fat more rapidly than did the lipoma of other patients. Among the subjects studied, there was great variation in the rate of acetate incorporation into mixed lipids by normal subcutaneous adipose tissue. In the rat, it has been found that there is a decrease in the in vitro rate of acetate incorporation into mixed lipids by adipose tissues with aging. ${ }^{1}$ As can be seen in Figure 1, the variation in lipid synthesis among the subjects studied bears no systematic relationship to their ages.

The rates of acetate incorporation into mixed lipids mentioned above have been related to the unit of wet weight of tissue. Normal adipose tissue was found to have a relatively higher nitrogen and lower lipid content than lipoma (Table I). When the rates of acetate incorporation into the mixed lipids are referred to these units, the difference in the rates of lipid synthesis between the two tissues are magnified (Table II). The ratio of the rate of oxidation of acetate to $\mathrm{CO}_{2}$ by lipomas to that of the normal adipose tissue of the same subject did not differ significantly from 1.0 whether related to units of wet weight, nitrogen, or lipid-

${ }^{1}$ Benjamin, W., Kundel, H., and Gellhorn, A. Unpublished observations.

TABLE III

Fatty acids in normal adipose tissue and lipoma *

\begin{tabular}{crrrrr}
\hline \hline Fatty acids $\dagger$ & \multicolumn{1}{c}{ Normal } & \multicolumn{1}{c}{ Lipoma } & Fatty acids $\dagger$ & Normal & \multicolumn{1}{c}{ Lipoma } \\
\hline C12 & $0.35 \pm 0.025$ & $0.35 \pm 0.017$ & C18 & $6.0 \pm 0.267$ & $5.3 \pm 0.115$ \\
C14 & $2.40 \pm .069$ & $2.50 \pm .053$ & C18-1 & $49.9 \pm .325$ & $49.9 \pm .400$ \\
C16 & $24.60 \pm .267$ & $25.60 \pm .354$ & C18-2 & $9.5 \pm .143$ & $9.6 \pm .209$ \\
C16-1 & $5.60 \pm .253$ & $5.70 \pm .014$ & & &
\end{tabular}

* These data are weighted mean values, the standard error of the mean for 4 to 14 separate samples of normal adipose tissue and lipoma from each of 9 subjects. The figures are given as percentages \pm the standard error of the mean.

$\dagger$ Designation of fatty acids as in Figure 2. 


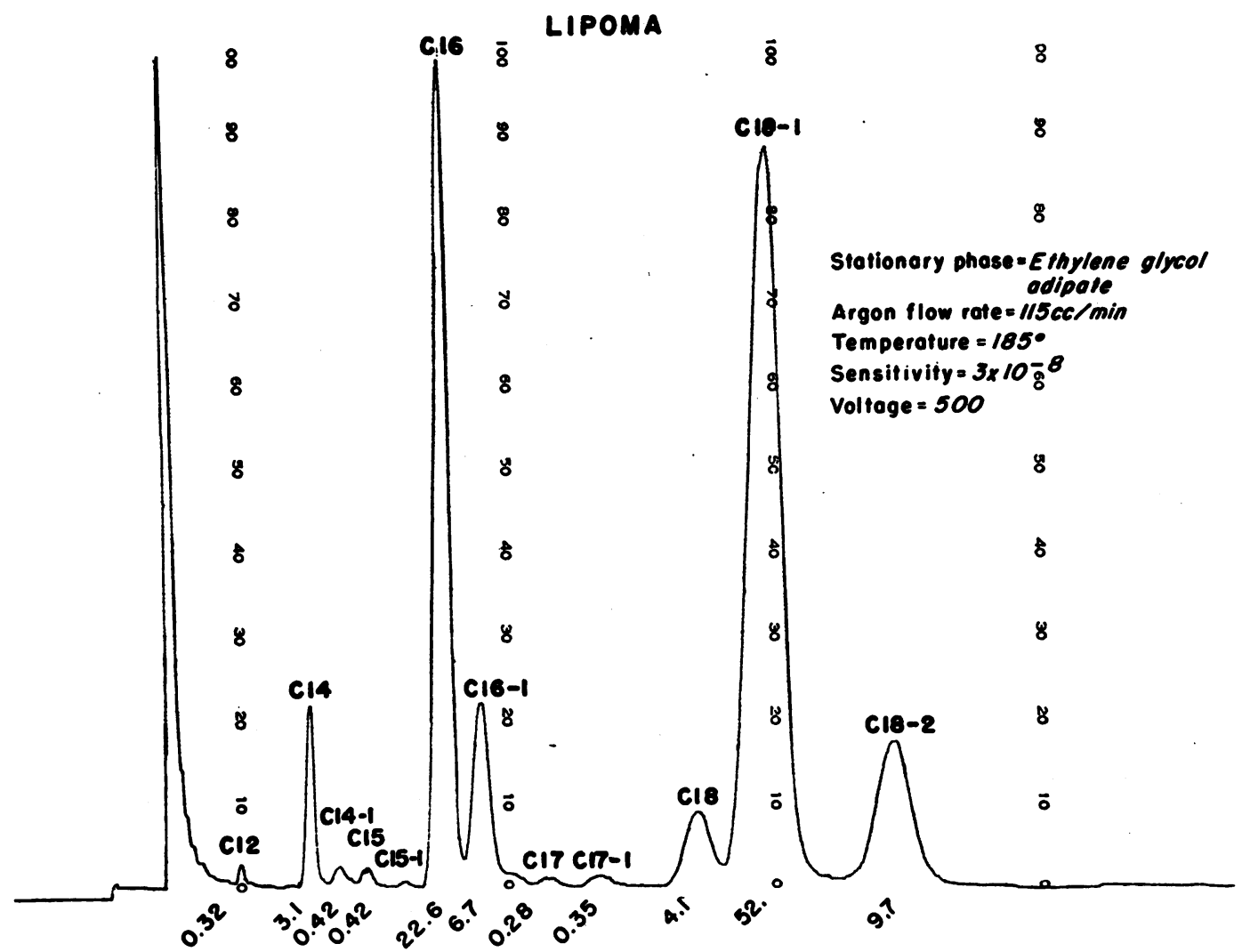

NORMAL TISSUE

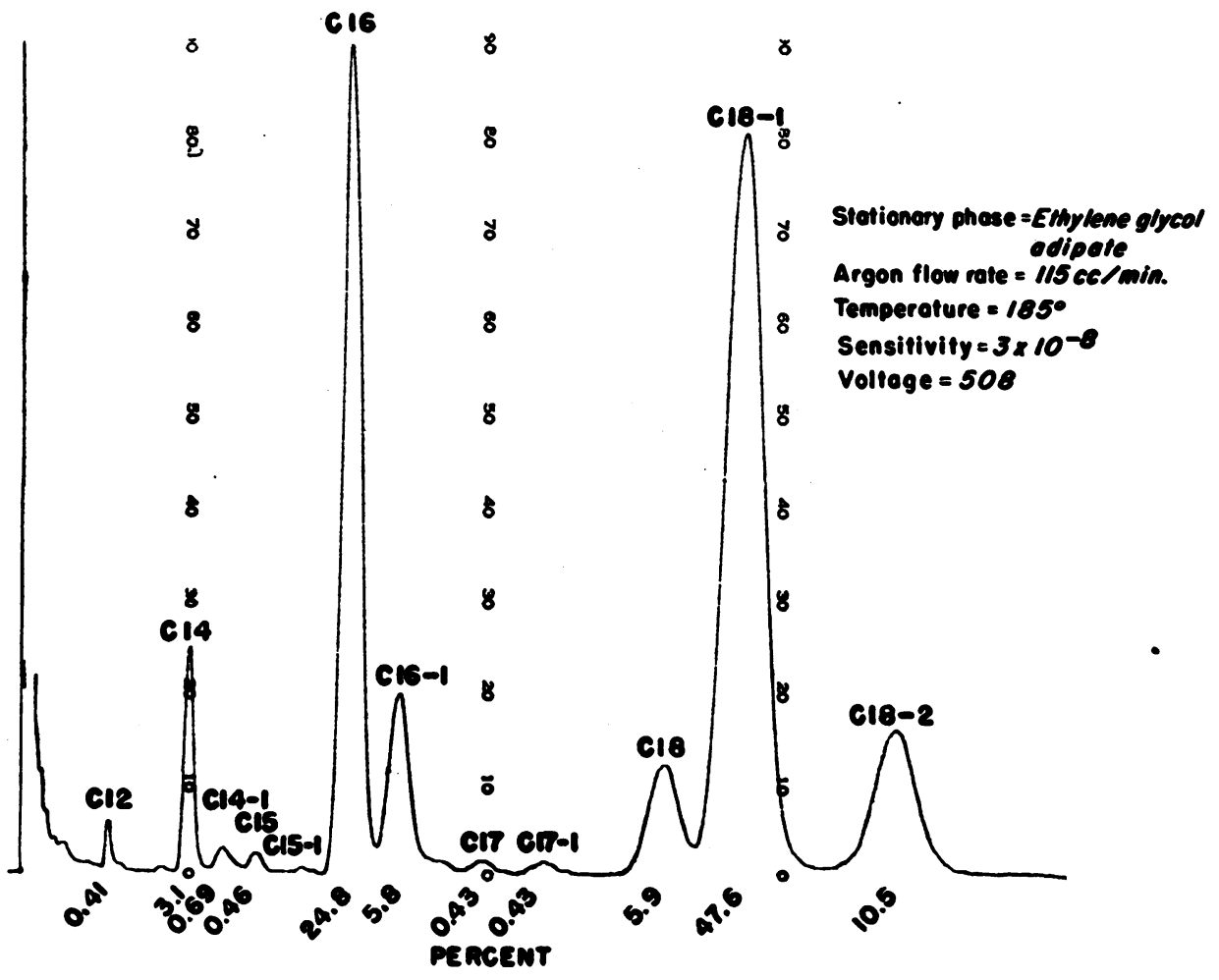

Fig. 2. See legend at bottom of page 929. 
TABLE IV

Acetate-1-C $C^{14}$ incorporation into lipid components of normal adipose tissue and medium *

\begin{tabular}{|c|c|c|c|c|c|c|c|c|}
\hline & $\begin{array}{l}\text { Mixed } \\
\text { lipidt }\end{array}$ & Sp. act. $\ddagger$ & $\begin{array}{l}\text { Mixed lipid } \\
\text { triglyceride† }\end{array}$ & Sp. act. & $\begin{array}{l}\text { Mixed lipid } \\
\text { free fatty } \\
\text { acidt }\end{array}$ & Sp. act. & $\begin{array}{l}\text { Triglyceride } \\
\text { fatty acidt }\end{array}$ & Sp. act. \\
\hline Tissue & $\begin{array}{c}33.0 \\
(27.5-41.4)\end{array}$ & $\begin{array}{c}0.047 \\
(0.038-0.060)\end{array}$ & $\begin{array}{c}35.0 \\
(27.5-42.5)\end{array}$ & $\begin{array}{c}0.048 \\
(0.038-0.059)\end{array}$ & $\begin{array}{c}0.35 \\
(0.22-0.39)\end{array}$ & $\begin{array}{c}0.078 \\
(0.045-0.133)\end{array}$ & $\begin{array}{c}28.4 \\
(19.5-38.7)\end{array}$ & $\begin{array}{c}0.033 \\
(0.020-0.050)\end{array}$ \\
\hline Medium & $\begin{array}{c}0.35 \\
(0.25-0.39)\end{array}$ & $\begin{array}{c}0.006 \\
(0.004-0.007)\end{array}$ & $\begin{array}{c}0.050 \\
(0.038-0.959)\end{array}$ & $\begin{array}{c}0.001 \\
(0.0009-0.0015)\end{array}$ & $\begin{array}{c}0.30 \\
(0.22-0.42)\end{array}$ & $\begin{array}{c}0.026 \\
(0.017-0.029)\end{array}$ & . & \\
\hline
\end{tabular}

* These are data for a single experiment. The mean value for radioactivity in the total lipid and the other lipid components was calculated by multiplication of the specific activity of the component by the total milligrams present per gram wet weight of adipose tissue. The values in parenmultiplication of the specific activity of the component by the total
theses indicate the range of determinations on 4 separate samples.

$\dagger$ Values shown are $\mu \mathrm{c} \times 10^{-2} / \mathrm{g}$ wet weight.
$t$ -

$\ddagger$ Sp. act. = specific activity in $\mu \mathrm{c} \times 10^{-2} / \mathrm{mg}$.
$\ddagger$ Salues

free weights of the tissues (Table II). Thus, the increased rate of fat biosynthesis by lipomas was 5 to 13 times greater than the normal tissue, depending upon the reference unit selected; the average rate of acetate-1- $\mathrm{C}^{14}$ oxidation to $\mathrm{C}^{14} \mathrm{O}_{2}$ was not significantly different between lipoma and normal adipose tissue, regardless of the reference unit used for calculation.

The proportion of the newly synthesized mixed lipid radioactivity transferred to the medium by lipoma and normal adipose tissue ranged from 1 to 34 per cent and the mean ratio of lipoma: normal was 1.05 . It was found that an increasing amount of the mixed lipid radioactivity appeared in the medium with time but the proportion of this, relative to the total radioactivity in the mixed lipids, remained constant.

Composition of normal subcutaneous adipose tissue and lipoma. Gas-liquid chromatographic analysis of the fatty acids from normal adipose tissue and lipoma revealed that oleic and palmitic acids predominated (Figure 2 and Table III). There were no qualitative or significant quantitative differences in the fatty acid composition of lipoma compared with normal fat. The seven fatty acids indicated in Table III accounted for about 98 per cent of all the fatty acids present in these tissues. Twenty-six fatty acids, in addition to those listed in Table III, were identified in the fat of the tissues here studied in a capillary column gas-liquid chromatographic analysis. ${ }^{2}$ These fatty acids, however, comprise less than 2 per cent of the total fatty acid composition. No qualitative differences in these minor (by criterion of weight) fatty acid components were noted between normal adipose tissue and lipoma. The standard error of the mean shown for each fatty acid in Table III indicates the small variation noted between samples from different subjects. A statistical comparison of the variation of fatty acid composition within sources and between sources led to the conclusion that there was no greater variation in the fatty acid composition between subjects than in the same subject.

Distribution of $C^{14}$ in lipid components of tissue and medium. More than 90 per cent of the tissue lipid radioactivity was present in the triglyceride and no more than 1.5 per cent was in the free fatty acids of the tissue (Tables IV and V). In the medium, on the other hand, the radioactivity was found predominantly in the free fatty acid fraction. Hydrolysis of the tissue triglycerides revealed that 80 per cent of the radioactivity was in the fatty acids. Although no significant difference in the distribution of the incorporated ace-

${ }^{2}$ We wish to acknowledge the assistance of Dr. S. R. Lipsky, Yale University School of Medicine, in this analysis and the generous advice given by him, Dr. Evan Horning and Dr. Charles C. Sweeley, National Heart Institute, Bethesda, Md., and Dr. David Turner, Sinai Hospital, Baltimore, Md., in our studies with gas-liquid chromatography.

Fig. 2. GAS-LiQUid CHROMATOGRAPHiC RECORDS OF METHYL ESTERS OF FATTY ACIDS ISOLATED FROM LIPOMA AND NORMAL ADIPOSE TISSUE. The designations above each peak identify the fatty acid according to carbon chain length (e.g., C12 dodecanoic acid) and number of unsaturated bonds (e.g., monoenoic C16-1 and dienoic C18-2). The numbers under each peak refer to the percentage of the total fatty acids represented by the particular fatty acid (e g., C18-1, 9-octadecenoic açid or oleic acid, comprisęs 52 per cent of the total fatty acids in the lipoma here shown). 
TABLE V

Distribution of radioactivity in lipid fractions

\begin{tabular}{lccc}
\hline \hline & Mixed lipid triglyceride/mixed lipid & Mixed lipid free fatty acid/mixed lipid & Triglyceride fatty acid/triglyceride \\
\hline Normal $[6]^{*}$ & $\%$ & $\%$ & $\%$ \\
Tissue & 99.7 & 0.9 & 79.1 \\
Medium & 20.3 & 78.0 & \\
Lipoma [3] & & & 109.0 \\
Tissue & 90.4 & 1.3 & \\
Medium & 11.2 & 78.0 & \\
\hline
\end{tabular}

* The numbers in brackets indicate the number of experiments from which the mean values have been calculated.

tate-1- $\mathrm{C}^{14}$ was found between the normal tissue and the lipoma, it is apparent that in the adipose tissues of man as in the rodent (15) there is a small free fatty acid intracellular pool and a large triglyceride pool. The lipid which is transferred across the cell membrane is predominantly in the form of the free fatty acid.

All of the fatty acids isolated from adipose tissue incubated with acetate-1-C ${ }^{14}$ were labeled (Table VI). The rate of $\mathrm{C}^{14}$ incorporation into the saturated fatty acids is greater than into the unsaturated fatty acids. Although the absolute amount of radioactivity was greater in the individual fatty acids isolated from lipoma than from normal, the distribution of the radioactivity among the fatty acids as shown by the relative specific activity was essentially the same in lipoma and in normal adipose tissue. The percentage of the total radioactivity recovered in the myristic acid (C-14) of lipoma was high in one experiment and comparable to that of normal in the other. This accounts for the higher mean relative specific

TABLE VI

The specific activities of fatty acids of the mixed lipids of normal adipose tissue and lipoma following incubation with acetate-1- $C^{14}$ *

\begin{tabular}{|c|c|c|c|c|c|c|}
\hline \multirow{2}{*}{$\begin{array}{l}\text { Fatty } \\
\text { acidt }\end{array}$} & \multicolumn{2}{|c|}{$\begin{array}{l}\text { Per cent of } \\
\text { total fatty } \\
\text { acids }\end{array}$} & \multicolumn{2}{|c|}{$\begin{array}{l}\text { Per cent of } \\
\text { total cpm } \\
\text { recovered }\end{array}$} & \multicolumn{2}{|c|}{$\begin{array}{l}\text { Relative sp. } \\
\text { act. } f\end{array}$} \\
\hline & $\mathbf{N}$ & $\mathbf{L}$ & $\mathbf{N}$ & L & $\mathbf{N}$ & L \\
\hline $\begin{array}{l}\text { C12 } \\
\text { C14 } \\
\text { C16 } \\
\text { C16-1 } \\
\text { C18 } \\
\text { C18-1 } \\
\text { C18-2 }\end{array}$ & $\begin{array}{r}1.3 \\
3.6 \\
18.9 \\
13.6 \\
57.1 \\
47.3 \\
11.8\end{array}$ & $\begin{array}{r}1.2 \\
3.6 \\
20.3 \\
10.5 \\
4.1 \\
43.5 \\
15.1\end{array}$ & $\begin{array}{r}3.4 \\
9.2 \\
45.2 \\
7.4 \\
22.8 \\
3.6 \\
7.1\end{array}$ & $\begin{array}{r}2.7 \\
23.9 \\
49.6 \\
3.3 \\
11.3 \\
5.2 \\
2.1\end{array}$ & $\begin{array}{l}2.20 \\
2.91 \\
2.51 \\
0.58 \\
4.71 \\
0.05 \\
0.74\end{array}$ & $\begin{array}{l}2.32 \\
7.82 \\
2.52 \\
0.30 \\
3.73 \\
0.12 \\
0.16\end{array}$ \\
\hline
\end{tabular}

* Results of 2 experiments; all analyses were determined at least in duplicate. $\quad \mathrm{N}=$ normal, $\mathrm{L}=$ lipoma.

$t$ Designation of fatty acids as in Figure 2.

$\ddagger$ The relative specific activity represents: $\frac{\dot{\%} \text { of total } \mathrm{cpm} \text { recovered }}{\% \text { of total fatty acids }}$ activity of the myristic acid of the lipoma than of the normal. The finding of small amounts of radioactivity in the essential fatty acid, linoleic (C18-2), was unexpected. This could represent contamination from other labeled fatty acids; isolation and degradation of the linoleic acid will be required for interpretation of the result.

\section{DISCUSSION}

This study demonstrates that normal adipose tissue of man can incorporate acetate into lipids in vitro. The rate of acetate incorporation per gram normal adipose tissue per hour among the subjects studied ranged from 0.1 to 130 m $\mu$ moles. This may be compared to 34 and 23 m $\mu$ moles acetate incorporation per gram wet weight per hour of human leukocytes and platelets, respectively (16). Although the median in vitro rate of about $1 \mathrm{~m} \mu$ mole acetate incorporated per gram adipose tissue per hour does not seem high, recognition that this tissue constitutes 20 per cent of the body weight provides a better indication of its importance in fat metabolism.

In the human subjects whose subcutaneous adipose tissue was studied, there was great variation in the in vitro rate of acetate incorporation into the mixed lipids. The epididymal fat pads from inbred strains of rats maintained under constant laboratory conditions and on a standard diet have a less variable in vitro rate of fat biosynthesis when the tissue from animals of the same age are studied. With aging, this rate declines from a mean of $7 \mu$ moles per $g$ epididymal adipose tissue in animals weighing $80 \mathrm{~g}$, to $0.7 \mu$ moles in $300 \mathrm{~g}$ animals. ${ }^{1}$ In the present studies of human adipose tissue, no correlation between fat synthesis and age, sex, or ethnic origin could be demonstrated. 
In contrast to the variability of the rates of lipid synthesis from one human subject to another, was the small deviation in the fatty acid composition of the adipose tissue from one person to the next. Observations of Moore and Cook on human subjects in Scotland showed essentially the same fatty acid composition as that reported here (17); Hirsch and co-workers have also emphasized the constancy of the fatty acid pattern in human adipose tissue (18). The uniformity of the adipose tissue fatty acid composition may reflect an overall similarity of the dietary fat intake among the subjects studied. The patients were, however, unselected and came from all economic groups as well as from different racial and national aggregates within metropolitan New York. Therefore, although not specifically determined, it is reasonable to assume considerable differences in dietary habits. If, as seems likely, this also implies differences in the composition of the fat intake, then active physiological regulation of the adipose tissue triglyceride composition must exist. Cellular control mechanisms for maintaining the constancy of the adipose tissue fatty acid composition are not known. One aspect of this may, however, be revealed in the present experiments. The in vitro studies with human adipose tissue have demonstrated that the synthesized lipid which appears in the medium is unesterified. These data are in accord with the observations of Reshef, Shafrir and Shapiro who found that in rat adipose tissue, unesterified palmitic acid is transferred from the tissue to the medium (19). In man, Dole (20), Gordon and Cherkes (21), Spitzer and Miller (22), and Laurell (23) have observed changes in the serum free fatty acids under conditions of fat mobilization from adipose tissue which indicate that fatty acids, not triglycerides, are released. The present results also demonstrate that there is less than 1.5 per cent of newly synthesized lipid present as free fatty acid in the cell and the remainder is esterified. In the studies of rat mesenteric adipose tissue, Shapiro, Chowers and Rose found that stearate-1-C $\mathrm{C}^{14}$ was incorporated into the cellular triglycerides; only a small proportion was present as the free acid (15). From these observations, it is suggested that fatty acid synthesized in the cytoplasm is immediately esterified and stored in the intracellular triglyceride reservoir or transferred to the extracellular fluids
This rapid disposition to one or another compartment provides flexibility which may facilitate the maintenance of a constant fatty acid composition.

It has been stated and generally accepted that lipomas do not participate in the body economy when there is a demand for fat mobilization through starvation or inanition. The clinical observation on which this allegation is based has been questioned (24) and the in vitro studies which have shown that radioactive lipids formed during incubation do appear in the medium also indicate that the potential mechanisms for mobilization of lipoma lipid exist.

At the outset of this study, several hypotheses were formulated which might characterize the fundamental difference between the lipoma and the normal adipose tissue from which it arises. Thus, a localized accumulation of fat could occur if the cells involved had a smaller than normal capacity to oxidize fatty acids, or if there were impairment in the pathway for the mobilization of fat from the cells, or if there were a greater rate of fat synthesis in the tumor than in the normal adipose tissue. One other possibility considered was that there might be a qualitative difference in the biosynthetic pathway which would lead to the formation of fat with a different chemical composition from that of the normal adipose tissue. It is recognized that in vivo there are many factors influencing lipid synthesis which cannot be evaluated in the in vitro system. Nevertheless, the finding that the lipomas generally incorporate acetate into fatty acids at a greater rate than the normal adipose tissue from the same subject, whereas there was no consistent difference between these two tissues in the rates of acetate oxidation to $\mathrm{CO}_{2}$, the proportion of newly synthesized lipid transferred to the medium, or the fatty acid composition, suggests that a disturbance in lipid synthesis is a major factor leading to fat accumulation in the lipoma.

\section{SUMMARY}

1. The rate of acetate-1- $\mathrm{C}^{14}$ incorporation in vitro into mixed lipids of lipomas and normal human subcutaneous adipose tissue from the same subject was greater in the tumor than in the normal tissue in 18 of 20 experiments. No significant difference in the rate of acetate-1- $\mathrm{C}^{14}$ incorporation into $\mathrm{C}^{14} \mathrm{O}_{2}$ or in the proportion of isotopically la- 
beled lipid transferred to the medium was found between the two types of adipose tissue.

2. Marked variation was observed in the rate of acetate incorporation into mixed lipids by subcutaneous adipose tissue among the 20 subjects studied. This could not be correlated with age, sex or race.

3. In contrast to the variability of lipid synthesis as measured by acetate incorporation into the mixed lipids, no significant variation was found in the fatty acid composition of the subcutaneous fat between subjects or between the normal adipose tissue fat and that of lipomas.

4. Studies of the distribution of radioactivity in lipid components of adipose tissue following incubation with acetate-1-C ${ }^{14}$ demonstrated about 1 per cent of the total in the tissue free fatty acids and the remainder in the triglycerides. Eighty per cent of the triglyceride radioactivity was recovered in the fatty acids. Similar studies of the lipids in the medium showed recovery of about 90 per cent of the radioactivity in the free fatty acids and the remainder in triglycerides. The rate of accumulation of $\mathrm{C}^{14}$ was greater in the saturated fatty acids than in the unsaturated acids in the normal adipose tissue and lipoma.

\section{REFERENCES}

1. Wertheimer, E., and Shapiro, B. The physiology of adipose tissue. Physiol. Rev. 1948, 28, 451.

2. Shapiro, B., and Wertheimer, E . The metabolic activity of adipose tissue. A review. Metabolism 1956, 5, 79.

3. Hausberger, F. X., Milstein, S. W., and Rutman, R. J. The influence of insulin on glucose utilization in adipose and hepatic tissues in vitro. J. biol. Chem. 1954, 208, 431.

4. Winegrad, A. I., and Renold, A. E. Studies on rat adipose tissue in vitro. I. Effects of insulin on metabolism of glucose, pyruvate and acetate. J. biol. Chem. 1958, 233, 267.

5. Ball, E. G., Martin, D. B., and Cooper, O. Studies on the metabolism of adipose tissue. I. Effect of insulin on glucose utlization as measured by manometric determination of carbon dioxide output. J. biol. Chem. 1959, 234, 774.

6. Colowick, S. P., and Kaplan, N. O. Methods in Enzymology. New York, Academic Press, 1955, vol. 1 , p. 5 .

7. Umbreit, W. W., Burris, R. H., and Stauffer, J. F. Manometric Techniques and Related Methods for the Study of Tissue Metabolism. Minneapolis, Burgess, 1945.
8. Davidson, J. D., and Feigelson, P. Practical aspects of internal-sample liquid-scintillation counting. Int. J. appl. Radiat. 1957, 2, 1.

9. Folch, J., Lees, M., and Sloane Stanley, G. H. A simple method for the isolation and purification of total lipides from animal tissues. J. biol. Chem. 1957, 226, 497.

10. Borgström, B. Investigation on lipid separation methods. III. Separation of tri-, di-, 1-mono- and 2-mono-glycerides. Acta physiol. scand. 1954, 30, 231.

11. James, A. T., and Martin, A. J. P. Gas-liquid chromatography: The separation and identification of the methyl esters of saturated and unsaturated acids from formic acid to $n$-octadecanoic acid. Biochem. J. 1956, 63, 144.

12. Lipsky, S. R., Landowne, R. A., and Godet, M. R. The effects of varying the chemical composition of the stationary liquid on the resolution of the long chain saturated and unsaturated fatty acid esters by gas-liquid chromatography. Biochim. biophys. Acta 1959, 31, 336.

13. Craig, B. M., and Murty, N. L. The separation of saturated and unsaturated fatty acid esters by a gasliquid chromatography. Canad. J. Chem. 1958, 36, 1297.

14. Karmen, A. Gas chromatography and lipid metabolism. Amer. Heart J. 1960, 59, 937.

15. Shapiro, B., Chowers, I., and Rose, G. Fatty acid uptake and esterification in adipose tissue. Biochim. biophys. Acta 1957, 23, 115.

16. Marks, P. A., Gellhorn, A., and Kidson, C. Lipid synthesis in human leukocytes, platelets, and erythrocytes. J. biol. Chem. 1960, 235, 2579.

17. Moore, C. H., and Cook, R. P. Human adipose tissue (abstract). Biochem. J. 1959, 73, 43p.

18. Hirsch, J., Farquhar, J. W., Ahrens, E. H., Jr., Peterson, M. L., and Stoffel, W. Studies of adipose tissue in man: A microtechnic for sampling and analysis. Amer. J. clin. Nutr. 1960, 8, 499.

19. Reshef, L., Shafrir, E., and Shapiro, B. In vitro release of unesterified fatty acids by adipose tissue. Metabolism 1958, 7, 723.

20. Dole, V. P. A relation between non-esterified fatty acids in plasma and the metabolism of glucose. J. clin. Invest. 1956, 35, 150.

21. Gordon, R. S., Jr., and Cherkes, A. Unesterified fatty acid in human blood plasma. J. clin. Invest. 1956, 35, 206.

22. Spitzer, J. J., and Miller, H. I. Unesterified fatty acids and lipid transport in dogs. Proc. Soc. exp. Biol. (N. Y.) 1956, 92, 124.

23. Laurell, S. Plasma free fatty acids in diabetic acidosis and starvation. Scand. J. clin. Lab. Invest. 1956, 8, 81.

24. Wells, H. G. Adipose tissue, a neglected subject. J. Amer. med. Ass. 1940, 114, 2177. 